\title{
A tentative guide for thoracic surgeons during COVID-19 pandemic
}

\author{
Ahmed Ghoniem', Amr Abdellateef ${ }^{2}$, Amr Ibrahim Osman ${ }^{1}$, Hany Hasan Elsayed ${ }^{3}$, Hussein Elkhayat ${ }^{1 *}$ (D) and \\ Waleed Adel $^{4}$
}

Keywords: COVID-19, Infection control, Thoracic, Surgery

Currently, there is not enough evidence to support the best practice for thoracic surgery practice during pandemic and the situation is highly dynamic on day to day basis.

Thoracic surgery may not seem to be in the frontline with managing COVID-19 patients, but we do have a key role to play and this must be planned. In response to pressures of the current pandemic, the elective component of our work has stopped. However, the non-elective patients (emergency, urgent, and trauma) will continue to need appropriate care and reactivation of service after situation becomes more stable.

We should seek to provide the best local solutions in conjunction with the recent national guidelines to continue the proper management of patients while ensuring proper resource allocation in response to COVID-19 with proper protection to the surgical stuff. In addition, we need to consider the possibility that the surgical facility for emergency surgery may be compromised in the near future due to a combination of factors including medical staff sickness, supply chain, and the use of theaters and anesthetic staff work in ICU instead. This is a possible scenario and plans are needed.

As the wider healthcare response intensifies, we may also need to work outside of our specific areas of training and expertise, and we must plan to learn new skills and practice.

Proper communication (could be telecommunication) with cardiothoracic patients awaiting operations is a

\footnotetext{
* Correspondence: Dr_khayat@hotmail.com

${ }^{1}$ Cardiothoracic Surgery Department, Assiut University Hospitals, Assiut

University, Assiut 71526, Egypt

Full list of author information is available at the end of the article
}

must in the for-coming period. Explaining that there is no harm to wait for a few weeks for appropriate cases and the plan to allocate resources can provide re assurance for many elective patients feeling the danger of delay. Maximize virtual follow-up (phone call check) to avoid the need for patients to attend hospital. Consenting patients for surgery in this period should always include a hospitalacquired risk to develop a COVID-19 infection.

In this review, we try to point out the idea of triage of thoracic surgery patients, precautions for use of bronchoscopy, and chest tubes as the most procedures done with possible aerosol generation and when can we reactivate our thoracic surgery service.

\section{Thoracic surgery triage during pandemic \\ Phase 1 (semi-urgent cases) of the COVID-19}

Here, the hospital resources are not exhausted, COVID trajectory is not in a rapid escalation phase, and the tertiary center ICU vent capacity is still available. Surgical services are offered for those where survival could be affected in the next few days if no intervention is performed (Table 1) [1].

No standard definition exists so far for the urgent cases that need to be done nor consensus on which patient cannot wait without further progression and surgeons will always balance between patients with risk of significant deterioration and availability of resources [2].

Avoid the routine use of critical care unit wherever possible (pre-op preparation, ERAS, pain relief)

\section{Phase 2: urgent setting}

In this phase we see many COVID-19 patients with limited ICU capacity and an escalating COVID trajectory.

\section{Springer Open}

(อ) The Author(s). 2020 Open Access This article is licensed under a Creative Commons Attribution 4.0 International License, which permits use, sharing, adaptation, distribution and reproduction in any medium or format, as long as you give appropriate credit to the original author(s) and the source, provide a link to the Creative Commons licence, and indicate if changes were made. The images or other third party material in this article are included in the article's Creative Commons licence, unless indicated otherwise in a credit line to the material. If material is not included in the article's Creative Commons licence and your intended use is not permitted by statutory regulation or exceeds the permitted use, you will need to obtain permission directly from the copyright holder. To view a copy of this licence, visit http://creativecommons.org/licenses/by/4.0/. 
Table 1 Summary for decision-making in different pathologies during phase 1

\begin{tabular}{|c|c|c|}
\hline Pathology & What to operate & What to defer \\
\hline NSCLC & $\begin{array}{l}\text { - Solid or predominantly solid (>50\%) lung } \\
\text { cancer or presumed lung cancer } \geq 2 \mathrm{~cm} \text {, } \\
\text { clinical node negative } \\
\text { - Post-induction therapy cancer }\end{array}$ & $\begin{array}{l}\text { - Predominantly ground glass (<50\% solid) } \\
\text { nodules or cancers } \\
\text { - Solid nodule or lung cancer }<2 \mathrm{~cm} \\
\text { - Indolent histology (e.g., carcinoid, slowly } \\
\text { enlarging nodule) } \\
>\text { Alternatives include: } \\
\text { - SABR, neoadjuvant therapy } \\
\text { - Ablation, stent, or debulking for } \\
\text { endobronchial lesions }\end{array}$ \\
\hline Esophageal tumors & $\begin{array}{l}\text { - Esophageal cancer T1b or greater } \\
\text { - Stenting for obstructing esophageal tumor }\end{array}$ & $\begin{array}{l}\text { Esophageal cancer T1a/b (superficial) could } \\
\text { be managed endoscopically. }\end{array}$ \\
\hline Chest wall & $\begin{array}{l}\text { Chest wall tumors of high malignant potential } \\
\text { not manageable by alternative therapy }\end{array}$ & $\begin{array}{l}\text { Chest wall tumors of high malignant } \\
\text { potential manageable by alternative therapy }\end{array}$ \\
\hline Mediastinal tumors & $\begin{array}{l}\text { Symptomatic mediastinal tumors-diagnosis } \\
\text { not amenable to needle biopsy }\end{array}$ & $\begin{array}{l}\text { - Thymoma (non-bulky, asymptomatic) } \\
\text { - Posterior mediastinal neurogenic tumors }\end{array}$ \\
\hline Other oncothoracic interventions & $\begin{array}{l}\text { Staging to start treatment (mediastinoscopy, } \\
\text { diagnostic VATS for pleural dissemination) }\end{array}$ & $\begin{array}{l}\text { Pulmonary oligometastases-unless clinically } \\
\text { necessary for pressing therapeutic or } \\
\text { diagnostic indications (i.e., surgery will impac } \\
\text { treatment) }\end{array}$ \\
\hline Others & $\begin{array}{l}\text { - All emergency cases as massive hemothorax, } \\
\text { major airway injury, airway obstruction by } \\
\text { inhaled foreign body or advanced tracheal } \\
\text { stenosis, and diaphragmatic hernia with } \\
\text { strangulation } \\
\text { - Loculated empyema with sepsis that cannot } \\
\text { otherwise be treated } \\
\text { - Tension emphysematous bullae with } \\
\text { respiratory distress } \\
\text { - Recurrent pneumothorax with massive air leak }\end{array}$ & $\begin{array}{l}\text { - Pectus surgery } \\
\text { - Hyperhidrosis } \\
\text { - Bronchiectasis } \\
\text { - Tracheal resection in tracheostomized } \\
\text { patients } \\
\text { - Non-malignant pleural effusion } \\
\text { - Elective bullectomy }\end{array}$ \\
\hline
\end{tabular}

SBRT stereotactic body radiation therapy, VATS video-assisted thoracoscopic surgery

Surgical management only offered for those who would not survive for few days if not operated upon (Table 2) [1].

\section{Phase 3: full outbreak of COVID 19}

All resources are routed to COVID-19 patients and there is no ICU capacity.

Thoracic surgery procedures are only performed for patients who are likely to die within the next few hours if no intervention is performed (Table 3) [1].

\section{Trauma patients}

Management of trauma patients is highly dependent on healthcare facility because even if COVID-19 screening test is available at initial assessment, negative test results do not exclude the presence of infection [2].

So, if the patient needs emergency interventions, he should be considered as a positive case with the following precautions:

- Full personal protective equipment (gowns, gloves, surgical masks, and face shield) are highly recommended.

- Minimize transfer these patients to multiple areas inside the hospital.
- Diagnostic procedures that would not affect the decision should be avoided.

- All members of the trauma unit should be familiar with the infection control protocols.

If the patient needs urgent or elective interventions, $\mathrm{CBC}$, body temperature, and $\mathrm{CT}$ chest should be done first and reported if consistent with COVID-19 or not.

\section{Reactivation of thoracic surgery service}

Returning to the usual surgical routine is within the scope of every surgeon now. Too many factors need to be taken in consideration; the limited resources as chain of supplies, number of nurses, available ICU beds, personal protective equipment (PPE), the limited access to diagnostic procedures as pulmonary function tests, bronchoscopy and the availability of PCR, and other tests for every patients and medical stuff. Early results from CovidSurg study show that patients whom discovered to be COVID positive perioperatively had a high complication and mortality rates [3], making the decision for operating every non-urgent case during the pandemic without rolling out the possibility of infection is a high risk operation. As a result, a very large number of operations will be postponed due to disruption caused by COVID-19 and in a recent study they concluded that 
Table 2 Summary for decision-making in different pathologies during phase 2

\begin{tabular}{|c|c|c|}
\hline Pathology & What to operate & What to defer \\
\hline NSCLC & $\begin{array}{l}\text { - Tumor-associated infection-compromising, } \\
\text { but not septic (e.g., debulking for } \\
\text { post-obstructive pneumonia) } \\
\text { - Tumor associated with hemorrhage, not } \\
\text { amenable to nonsurgical treatment. } \\
\text { - Threatened airway }\end{array}$ & $\begin{array}{l}\text { - As phase } 1 \text { in addition to any non-complicated } \\
\text { NSCLC by infection or hemorrhage or airway } \\
\text { obstruction } \\
\text { - Alternatives as phase } 1 \text { in addition to referral to } \\
\text { phase } 1 \text { hospitals }\end{array}$ \\
\hline Esophageal cancer & Septic or non-septic perforation only & Non-complicated by perforation cases \\
\hline $\begin{array}{l}\text { Postoperative complications (hemothorax, } \\
\text { empyema, infected mesh, dehiscence of } \\
\text { airway, anastomotic leak with sepsis) }\end{array}$ & Hemodynamic stable or unstable patients & Minor wound infections \\
\hline Others & $\begin{array}{l}\text { - All emergency cases as massive hemothorax, } \\
\text { major airway injury, airway obstruction by } \\
\text { inhaled foreign body or advanced tracheal } \\
\text { stenosis, and diaphragmatic hernia with } \\
\text { strangulation } \\
\text { - Loculated empyema with sepsis that cannot } \\
\text { otherwise be treated } \\
\text { - Tension emphysematous bullae with respiratory } \\
\text { distress } \\
\text { - Recurrent pneumothorax with massive air leak }\end{array}$ & $\begin{array}{l}\text { - Pectus surgery } \\
\text { - Hyperhidrosis } \\
\text { - Bronchiectasis } \\
\text { - Tracheal resection in tracheostomized patients } \\
\text { - Non-malignant pleural effusion } \\
\text { - Elective bullectomy } \\
\text { - Retained bullets with no fear of migration or } \\
\text { embolization } \\
\text { - Empyema that can be drained by chest tube } \\
\text { - Pneumothorax for pleurodesis }\end{array}$ \\
\hline
\end{tabular}

NSCLC non-small cell lung cancer

it would take a median 45 weeks to clear the backlog of operations resulting from COVID-19 disruption if surgery services increase the normal surgical volume rate by $20 \%$ during the post-pandemic era [4].

\section{Precautions for bronchoscopy}

- Bronchoscopic procedures are aerosol-generating procedures (AGPs).

- Indications for bronchoscopy should consider the potential for transmission of COVID-19 infection.

- All foreign body inhalation patients with respiratory distress should have their bronchoscopy done without delay.

- Make sure that your bronchoscopy set is sterilized (autoclave preferred) before starting the procedure

- Minimize the personnel in OR to the least possible
- Standard Personal protective equipment (surgical masks, eye protection) for all bronchoscopy patients

- Avoid high flow jet oxygen ventilation whenever possible

For cases of suspected COVID-19, this should only occur in exceptional circumstances when bronchoscopy cannot be deferred and (FFP3 respirator, long-sleeved gown, gloves, eye protection) should be worn and safely taken off and dispose appropriately as instructed by infection control staff.

\section{Chest tube in era of COVID-19 Indications and triage}

Insertion of intercostal drain (ICD) during COVID-19 pandemic could be indicated for a well-known hospitalized COVID-19-positive patients or usual patients who

Table 3 Summary for decision-making in different pathologies during phase 3

\begin{tabular}{|c|c|c|}
\hline Pathology & What to operate & What to defer \\
\hline NSCLC & $\begin{array}{l}\text { - Threatened airway } \\
\text { - Tumor-associated severe infection } \\
\text { - Hemodynamically unstable patients with } \\
\text { tumor-associated hemorrhage }\end{array}$ & $\begin{array}{l}\text { As phase 1, } 2 \text { plus hemodynamically } \\
\text { stable patients with any complication }\end{array}$ \\
\hline Esophageal cancer & Septic perforation & As phase 1, 2 plus non-septic perforation \\
\hline Postoperative complications & $\begin{array}{l}\text { Only hemodynamically unstable patients, } \\
\text { critically compromised airway as active } \\
\text { bleeding not amenable to nonsurgical } \\
\text { management, dehiscence of airway, and } \\
\text { anastomotic leak with sepsis. }\end{array}$ & $\begin{array}{l}\text { As phase } 2 \text { plus any complication not } \\
\text { critically compromising the airway or } \\
\text { causing hemodynamic instability }\end{array}$ \\
\hline Trauma & $\begin{array}{l}\text { All emergency cases as massive hemothorax, } \\
\text { major airway injury, airway obstruction by } \\
\text { inhaled foreign body or advanced tracheal } \\
\text { stenosis, and diaphragmatic hernia with } \\
\text { strangulation }\end{array}$ & $\begin{array}{l}\text { As phase } 2 \text { plus any complication not } \\
\text { critically compromising the airway or } \\
\text { causing hemodynamic instability }\end{array}$ \\
\hline
\end{tabular}


visit any hospital emergency department for traumatic or non-traumatic pneumothorax or pleural effusion. Despite presence of theoretical higher risk of infection in case of dealing with COVID-19-positive patient, healthcare workers' (HCW) precautions may minimize that risk as $\mathrm{HCW}$ would take complete caution by wearing personal protective equipment (PPE) and by keeping vigilant not to catch infection. Actually, the silent risk is to go for ICD insertion in a COVID-19 asymptomatic carrier [5].

The symptoms that carry the indication for chest tube insertion could mask the symptoms of a COVID-19 infection. Examples include empyema and large pneumothoraces causing fever and dyspnea, similar to COVID-19 symptoms, so a triage can be carried out primarily and further categorization of patients according to urgency is better to be based on special protocol or algorithm for every thoracic surgery unit. Any patient should be dealt with as assumed COVID positive until proved otherwise [6,7].

\section{Preparation}

\section{Preparation of drainage system}

Higher risk of aerosol production is raised in cases of pneumothorax with active air leak. The most common available drainage system at our community is the traditional under water-seal collectors which have an outlet vent to atmosphere. When air passes from thoracic cavity to the water in the containers, it causes bubbling with the transmission of air via the outlet vent to the atmosphere causing potential environmental aerosol viral infection. Also, even though digital chest drainage systems do not have an outlet vent to room air, they are not closed systems and the air may escape from them into the air without any specific viral filter [8].

So, in spite of closed suction drainage system is advised to be used to limit aerosolization, there is a general acceptance on use of viral filter as purifying media between the drain and the suction system or the atmosphere whatever the open or closed drainage system is used. Site of application of the viral filter would be distal to the outlet vent. According to the recently published reports, different forms of high-efficiency particulate air (HEPA) viral filters have been used [6-8].

Use of viral filter in chest tubes has not been examined yet on evidence-based criteria, but it depends on the rationale of its proved ability to filter smaller viruses like hepatitis $C$ whose average diameter is of about $55 \mathrm{~nm}$ compared to SARS Cov-2 diameter which varies from 60 to $140 \mathrm{~nm}$ [8].

Lessening of viral load also could be managed at an earlier level through adding sterilizing solution like; dilute household bleach (5.25-6.15\% sodium hypochlorite) with ratio of 1:50 to the fluid in the water seal [6] ordinary betadine used for wound care and alcohol $70 \%$ were also used by many senior surgeons as they used to do in the TB era.

In advance preparation of the drainage system depends on creation of ready sterile connected set starts up by a suitable size chest drain firmly connected through a connector to an underwater seal container having sterile solution and its outlet vent is connected to HEPA filter through a cut endotracheal tube (Fig. 1). This pre-prepared drainage system is so crucial to prevent any potential aerosol infection in the time consumed preparing the drainage system after insertion of the ICD inside the thoracic cavity.

\section{Precaution during the technique}

-Before starting the procedure, prepare the whole connected drainage set including the drain and underwater seal carrying a viral filter as described before.

-It is better to direct the patient's face to the opposite side during the procedure and advise him to wear a surgical mask to reduce viral load exhaled (if not impairing his breathing).

-Make the skin incision as small as possible to avoid air or fluid leak around the tube.

-Once you open the pleura, take care of the first gush of air due to the sudden decompression that carry the potential maximum viral load. To lessen that gush, the surgeon can cover the skin incision by a wet gauze with the non-working hand while the other hand at the same

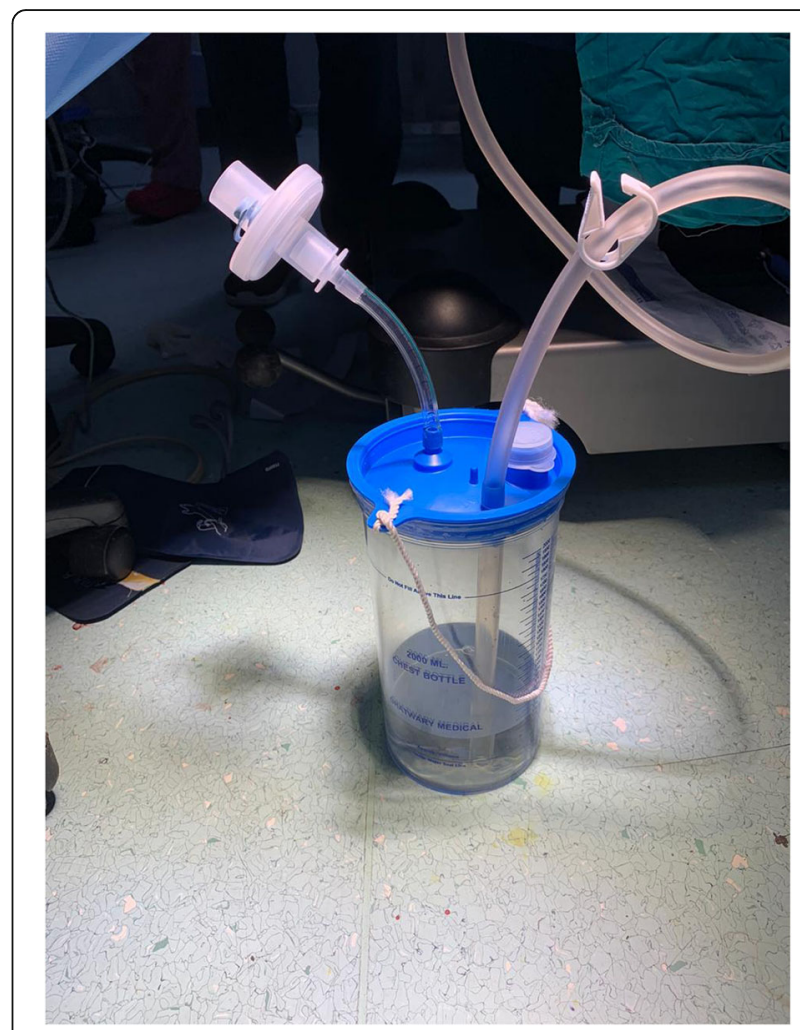

Fig. 1 Preparation of the drainage system 
time opening the pleura or inserting the tube. That gauze works as a valve mechanism to prevent exit of air through the skin till insertion of the tube.

-The maximum air leak and bubbling will be at the start with maximum viral load getting out through the vent passing by the viral filter. So, the underwater seal drain could be put temporarily in a loosely closed plastic bag to contain any increased aerosolization after primary pleural decompression, then that plastic bag would be removed.

-If the patient is mechanically ventilated, hold ventilation before entry into the pleural space or until connection of the tube to the drain if not.

-Tighten the skin incision around the tube to prevent any air leakage.

-After finishing the procedure, get rid of disposables along with PPE as per recommended local institutional protocol.

\section{Follow-up of the drain}

-Usual follow-up or dressing on the wound should be conducted by HCW while wearing N95 mask, face shield, eye google, gloves, and non-sterile gown.

-Testing of residual air leakage by asking the patient to cough or to take deep breath should be minimized. If it is necessary in case of absent digital calculation system of air leak, the patient should wear a mask and look at the opposite direction while doing that.

-Do not overhandle the tube, e.g., do not pull the tube if kinked as long as it is functioning well. Pulling out the tube will take the contaminated intrathoracic part exposed out.

-If needed, clamp the tube while changing the bottle system or connecting it.

-Follow-up with radiology is better to be done by portable $x$-ray device inside the ward or inside a specific radiology unit for COVID-positive patients with predetermined transport routes to decrease the possible hospital environmental contamination [9].

\section{Removal of the drain}

-Removal of the drain should be in a specific dressing room while wearing full PPE.

-Upon removal of the tube, the procedure should be airtight to prevent any air to get in or out from chest cavity. That could be done through pinching of the skin around the skin opening or covering the skin by a gauze soaked by ointment while pulling out the tube followed by fast tightening of the preplaced suture [6].

\section{Abbreviations}

AGP: Aerosol-generating procedures; ERAS: Enhanced recovery after surgery; FFP3: Filtering facepiece class 3; ICU: Intensive care unit; NSCLC: Non-small cell lung cancer; OR: Operating room; SBRT: Stereotactic body radiation therapy; VATS: Video-assisted thoracoscopic surgery

\section{Acknowledgements}

Authors would like to acknowledge the Egyptian Society of Cardiothoracic Surgery and its board especially prof. Elhusseiny Gamil for their valuable support and encouragement.

\section{Authors' contributions}

$A G$ : revise the whole manuscript. AA: share in writing the manuscript. AIO: collection of data. $\mathrm{HH}$ : share in writing the manuscript and revise the whole manuscript. HE: idea of the manuscript and arrangement of workforce. WA: share in writing the manuscript. All authors read and approved the final manuscript.

\section{Funding}

No funding

\section{Availability of data and materials}

Not applicable

Ethics approval and consent to participate

Not applicable

Consent for publication

Not applicable

Competing interests

None

\section{Author details}

${ }^{1}$ Cardiothoracic Surgery Department, Assiut University Hospitals, Assiut University, Assiut 71526, Egypt. ${ }^{2}$ Mansoura University, Mansoura, Egypt. ${ }^{3}$ Ain Shams University, Cairo, Egypt. ${ }^{4}$ Cairo University, Giza, Egypt.

Received: 7 May 2020 Accepted: 22 June 2020

Published online: 02 July 2020

\section{References}

1. Thoracic Surgery Outcomes Research Network I (2020) COVID-19 Guidance for Triage of Operations for Thoracic Malignancies: A Consensus Statement from Thoracic Surgery Outcomes Research Network. Ann Thorac Surg S0003-4975(20):30442-2. https://doi.org/10.1016/j.athoracsur.2020.03.005

2. Brian, M. and W. Douglas E. 2020, Definition of necessary surgery in the age of COVID-19: an interview with Douglas E. Wood.

3. Collaborative CO (2020) Mortality and pulmonary complications in patients undergoing surgery with perioperative SARS-CoV-2 infection: an international cohort study. Lancet

4. COVIDSurg Collaborative, D. Nepogodiev, and A. Bhangu (2020) Elective surgery cancellations due to the COVID -19 pandemic: global predictive modelling to inform surgical recovery plans. Br J Surg. https://doi.org/10. 1002/bjs. 11746

5. Li R et al (2020) Substantial undocumented infection facilitates the rapid dissemination of novel coronavirus (SARS-CoV-2). Science 368(6490):489-493

6. Pieracci FM et al (2020) Tube thoracostomy during the COVID-19 pandemic: guidance and recommendations from the AAST Acute Care Surgery and Critical Care Committees. Trauma Surg Acute Care Open 5(1):e000498

7. CARVALHO EDA, OLIVEIRA MVBD (2020) Safety model for chest drainage in pandemic by COVID-19. Revista do Colégio Brasileiro de Cirurgiões 47

8. Rajdeep, B., et al., COVID-19: chest drains with air leak - the silent 'super spreader'? 2020.

9. World Health Organization. 2020 Infection prevention and control during health care when novel coronavirus ( $\mathrm{nCoV}$ ) infection is suspected [cited 20205 june 2020 ]; Available from: https://www.who.int/publications/i/item/ infection-prevention-and-control-during-health-care-when-novelcoronavirus-(ncov)-infection-is-suspected-20200125.

\section{Publisher's Note}

Springer Nature remains neutral with regard to jurisdictional claims in published maps and institutional affiliations. 